\title{
Teaching Reform of Java Course based on CDIO for "Outstanding Engineers" Education in China
}

\author{
Jie Xiong \\ School of Elect. and Info. \\ Yangtze University \\ Jingzhou, China
}

\author{
Caiyun Liu \\ School of Info. and Math. \\ Yangtze University \\ Jingzhou, China
}

\author{
Yanqiu Ma \\ School of Elect. and Info. \\ Yangtze University \\ Jingzhou, China
}

\begin{abstract}
In order to training outstanding engineers for the emerging industry, the projects of "Plan for educating and training outstanding engineers" (P4ETOE) and "Strategic Emerging Pillar Industry Project" (SEPIP) have been carried out in the Electronics and Information Engineering specialty of Yangtze University, China in recent years. Since Java language is an important course of Electronics and Information specialty, a teaching reform was carried out on it to solve the problem of traditional teaching, focusing on the following three aspects: the theory teaching, the practice teaching, and assessment method. The teaching reform has been proven effective and successful based on the teaching practices of the P4ETOE and SEPIP experimental classes of Yangtze University. It can enhance the students' comprehensive abilities of engineering and innovation.
\end{abstract}

Keywords: outstanding engineering education; teaching reform; Java course; Electronics Information Engineering;

\section{INTRODUCTION}

The "Plan for educating and training outstanding engineers" (P4ETOE) of China is a major reform program to implement the National Medium and Long Term Education Reform and Development Program (2010-2020). It aims to train a large number of high-quality engineers, who have the capacities of innovation and practical skills of engineering to meet the needs of economic and social development [1] [2].

The projects of "Strategic Emerging Pillar Industry Project" (SEPIP) led by Hubei Province government and P4ETOE led by Department of Education of China have been carried out since 2010 and 2013, respectively. The Java Language is one of most important courses of the Electronics and Information specialty, which plays an important role in cultivating innovative and practical skills of engineering. However, there are many problems in the traditional teaching of Java course. It was considered difficult to teaching and learn by both students and teachers [3] [4]. In order to solve the problems mentioned above, a teaching reform has been carried out in the following three aspects: theory teaching, practice teaching and assessment method, based on P4ETOE and SEPIP projects. The teaching practice of the P4ETOE and SEPIP experimental classes of Yangtze University showed that our teaching reform is effective and successful.

\section{REFORM OF THEORY TEACHING METHOD}

Java is a course with difficult theory and emphasis on practise. It is likely for student who facing a large number of concepts and difficult theoretical knowledge to lose their interest in study, if the traditional teaching method is used. Hence, we introduced an international advanced engineering education mode "Conceive, Design, Implement, and Operate" (CDIO) [5], which is a engineering design task-oriented, project-driven teaching method to develop the students' engineering abilities.

\subsection{Using a project case as the main line}

We use a Java development case with medium-size as the main line to connect the isolated concepts and theoretical knowledge learned before. Students complete the tasks of submodule development, step by step, through the classroom learning, self-study, and interactive cooperation. They can understand the role of the knowledge points in the whole project case under the guidance of the main line of the project case.

The name of sub-modules and their corresponding knowledge points, using the library management system as an example, are listed in Table 1.

\subsection{Heuristic teaching}

(1) Problem-oriented

Using the project case as the main line, we design appropriate questions to guide students learn the knowledge through explorative study and solving the practical problem. The reasonable designed questions can lead students to active thinking, active learning and building their knowledge structure gradually. Some of the questions are listed in the Table 2. 
Table 1. Submodules of a project case and its corresponding knowledge

\begin{tabular}{|c|c|c|c|}
\hline Project Name & Submodule No. & Submodule Name & The Corresponding Knowledge Points \\
\hline \multirow{4}{*}{$\begin{array}{c}\text { Library Management } \\
\text { System }\end{array}$} & 1 & Class of student, book & Class and Object \\
\cline { 2 - 4 } & 2 & Different types of books, students & Class inheritance \\
\cline { 2 - 4 } & 3 & $\begin{array}{c}\text { Unique access interface for different } \\
\text { types of students }\end{array}$ & Solymorphism \\
\cline { 2 - 4 } & 4 & GUI for library manage system & Java database programming \\
\cline { 2 - 4 } & 5 & Library access module & Java network programming \\
\cline { 2 - 4 } & 6 & Remote access library module & J2EE Web programming \\
\hline
\end{tabular}

Table 2. Examples of designed questions

\begin{tabular}{|c|l|l|}
\hline Submodule No. & \multicolumn{1}{|c|}{ Designed Questions } & \multicolumn{1}{|c|}{$\begin{array}{c}\text { The Corresponding Knowledge } \\
\text { Points }\end{array}$} \\
\hline 1 & What is the common characteristics of books, students? & Abstract for a Class \\
\hline 2 & $\begin{array}{l}\text { What should we do if we need process a special type of book or different } \\
\text { type of students? }\end{array}$ & Inheritance of Class \\
\hline 3 & How to design a unique access interface for different types of students? & Polymorphism of Class \\
\hline 4 & $\begin{array}{l}\text { How to design a GUI for our library manage system? How to design a user } \\
\text { friendly interface? How to test the GUI? }\end{array}$ & Swing programming \\
\hline 5 & $\begin{array}{l}\text { How to design and develop a program to access a database such as Oracle, } \\
\text { SQL Server, or MySQL? }\end{array}$ & Java database programming \\
\hline 6 & $\begin{array}{l}\text { How to develop a program to send and receive data from network? How to } \\
\text { write a TCP/IP program using Java Language? }\end{array}$ & Java network programming \\
\hline 7 & $\begin{array}{l}\text { Why should we migrate the library manage system to the website? How to } \\
\text { migrate it to the website so that everyone could access it from internet by } \\
\text { browser? }\end{array}$ & J2EE Web programming \\
\hline
\end{tabular}

\section{(2) Group teaching}

Students were divided into several project groups. Each group consists of 3 or 4 students, including a leader. The leader led the other members to complete the whole library management system development process, such as design a Class, inheritance a Class, develop GUI using Swing, develop database access module, network communication module and migrate the application to the website. The Teacher acted as technical consultant and chief engineer guiding students to discover and solve problems. Through group teaching methods, the teamwork ability, engineering practice ability and innovation ability of students were cultivated.

\section{(3) Interactive teaching}

Sufficient time was reserved for each team to have a representation including implementation process, analysis method of the problem, and resolving measures. The students of other teams can actively ask questions, or put forward their own views. The teacher acts as a commentator. Every student could participate in the whole process of teaching and be motivated to learn through interactive teaching.

\subsection{Improving the CDIO abilities of teachers}

The quality of teachers is the key to the success of CDIO teaching. Teachers should improve their CDIO capabilities by participating in software development projects, and training projects. Only in this way, teachers could guide students to analyze and solve the problems from the perspective of engineers, and share their engineering experiments to their students effectively and easily.

\section{REFORM OF PRACTICE TEACHING}

Practice teaching is very helpful for training the engineering abilities and innovation spirit of the students. It is important for the engineering education of colleges and universities [6][7]. There are some problems in the practice teaching of the Java course, such as lacking of students' autonomy, irrational designed experimental projects, insufficient interaction between teachers and students, neglect of training the innovation ability and application ability of students. In order to cultivate students ability of engineering practice, we optimize and adjust the experimental content and change the experimental teaching method, using a engineering task as the main line. The experiments were divided four levels: basic experiment, design experiment, comprehensive experiment and course design, listed in the Table 3.

The basic experiment is mainly completed by extracurricular time self-study, which can not only solve the contradiction between experimental task and experimental time, but also can fully mobilize the enthusiasm and autonomy of students, exercise and cultivate students' basic programming ability, and lay a solid foundation for the follow-up experiments. The design 
Table 3. Multilevel Experiment System of Java Course

\begin{tabular}{|c|c|c|c|}
\hline Experiment Category & Experiment Content & Main Teaching Methods & Develop Skills \\
\hline $\begin{array}{l}\text { Fundamental } \\
\text { experiment }\end{array}$ & Design a Class, Initialize a Object & $\begin{array}{l}\text { Teacher demonstrates at classroom, } \\
\text { student self-study after class, Q\&A during } \\
\text { experimental class }\end{array}$ & $\begin{array}{l}\text { Deepen the understanding of the } \\
\text { basic concepts, master the basic } \\
\text { syntax of Class define }\end{array}$ \\
\hline $\begin{array}{l}\text { Design } \\
\text { Experiment }\end{array}$ & $\begin{array}{l}\text { Inheritance and Polymorphism of } \\
\text { Class, GUI programming using } \\
\text { Swing }\end{array}$ & $\begin{array}{l}\text { Grouping, fully prepared for the } \\
\text { experimental class, implementation and } \\
\text { Q\&A during the experimental class }\end{array}$ & $\begin{array}{l}\text { Training students to analyze and } \\
\text { solve problems, ability of the } \\
\text { basic engineering }\end{array}$ \\
\hline $\begin{array}{l}\text { Comprehensive } \\
\text { Experiment }\end{array}$ & $\begin{array}{l}\text { database programming, network } \\
\text { programming }\end{array}$ & $\begin{array}{l}\text { Grouping, experimental class } \\
\text { implementation, teacher on-site guidance }\end{array}$ & $\begin{array}{l}\text { Training system design and } \\
\text { analysis ability and engineering } \\
\text { ability }\end{array}$ \\
\hline Project Training & $\begin{array}{l}\text { Develop the library management } \\
\text { system, migrate it to the website }\end{array}$ & $\begin{array}{l}\text { Grouping, Complete in two weeks, } \\
\text { teachers on-site Q\&A and guidance }\end{array}$ & $\begin{array}{l}\text { Cultivate engineering practice } \\
\text { ability and innovation ability }\end{array}$ \\
\hline
\end{tabular}

experiment and the comprehensive experiment are carried out by grouping, which can train the students' teamwork ability and engineering practice ability, and also overcome the shortage of teachers in a certain extent. On the basis of the above three stages of practice, a two weeks dedicated time are spent to carry out curriculum design, which develops students' engineering practice and innovation.

\section{REFORM OF ASSESSMENT METHOD}

The traditional assessment method, which mainly depends on the final exam, is harmful to assess students' engineering ability. To ensure the effectiveness of teaching, we designed a diversified assessment method, referring to CDIO standards, to assess the students' basic personal ability, interpersonal skills, software development capabilities, and their theoretical knowledge.

The assessment method is described as following: (1) Dialy work, accounting for $10 \%$, including attendance, homework; (2) Assessment for the learning process, accounting for $60 \%$, which consists of the project self-assessment and teacher evaluation. The project self-assessment for each team member is conducted by the team leader according to the teamwork ability, practical engineering ability, innovation ability, assessment from other members. The teacher's assessment is based on the team's completion of the project, the effect of the project statement, and project report. (3) Final examination result, accounting for $30 \%$, using the traditional examination methods, assessment of students' theoretical knowledge, ability of algorithm design and programming.

Through strengthening the teaching process assessment, we could control each teaching links, guide students to improve the autonomy of learning, and train their abilities of teamwork, engineering practice, and innovation. The new assessment method could improve the teaching effectiveness by avoiding the students not study usually but drive a night car just before the final exam.

\section{CONCLUSION}

A systematic teaching reform has been carried out, based the projects of P4ETOE and SEPIP, on the aspects of theory teaching, practice teaching and assessment methods. The teaching reform has been proven effective and successful by the teaching practice of P4ETOE and SEPIP experimental classes of Yangtze University in recent years. It can enhance the students' comprehensive abilities of engineering and innovation, and help to cultivate outstanding engineers for the future.

\section{ACKNOWLEDGMENTS}

The research is supported jointly by the Teaching researching project of Yangtze University (JY2014010, JY2014042), The "Plan for educating and training outstanding engineers" (P4ETOE 2013), and the "Strategic Emerging Pillar Industry Project” (SEPIP 2012) of China.

\section{REFERENCES}

[1] Lin, J. 2010. Discussion on Some Reforms in Implementing 'Cultivation Program of Excellent Engineers', China Higher Education, 2010, No.17, 3032.

[2] Lin, J. 2011. On the professional Training Program of 'a Plan for Educating and Training Outstanding Engineers', Tsinghua Journal of Education, Vol. 32, No. 2, 47-55.

[3] Cao, F. 2016. Reform of a Java curriculum based on a CDIO active project-driven method, World Trans. Eng. Technol. Edu., Vol.14, No.1, 129-135.

[4] Li, Z. 2015, The application of hybrid flipped classroom in the course of Java programming, Proceedings of International Conf. On Info. Tech. in Med. and Edu., 637-641.

[5] Wang, L. Wu, X. and Li, L. 2016, Research on Engineering Education Mode Based on CDIO Concept: Take Food Machinery Major as an Example, Advance Journal of Food Science and Technology, Vol.10, No.10, 776-779.

[6] Liu, W. Jia, Y. Dong, Z. Et al. 2017, Research on practical teaching of software engineering specialty based on Java case library, Journal of Wuhan Polytechnie University, Vol.36, No.2, 110-113.

[7] Hosseini, R. Sirkia, T. Guerra, J. 2016. Animated Examples as Practice Content in a Java Programming Course, Proceeding SIGCSE'16, 540-545. 